\title{
PEMBEKALAN ANGKATAN MUDA SIAP KERJA KARANG TARUNA KELURAHAN CIBINONG MELALUI POLA RUMAH KARIR
}

\section{TRAINED THE YOUTH WORKING AGE OF KARANG TARUNA KELURAHAN CIBINONG MEMBER BY SIMPLE CAREER SCHEME TO ENTER THE WORK ENVIROMENT}

\author{
Salmah $^{1 a}$, A Rahmi ${ }^{1}$, F Andria ${ }^{1}$ dan Herdiyana ${ }^{1}$ \\ ${ }^{1}$ Universitas Pakuan, Jalan Pakuan Po Box 452 Bogor 16143 Jawa Barat Indonesia \\ aKorespondensi:Salma ; E-mail: salma@unpak.ac.id \\ (Diterima: 29-12-2018; Ditelaah: 28-12-2018; Disetujui: 02-02-2019)
}

\begin{abstract}
Karang taruna organization is a forum that can help the government to solve the society problem. Kabupaten Bogor which consist of 40 Kecamatan is an sample of an area that use karang taruna to grow and develop their area prosperity. One of them is Kelurahan Cibinong that have karang taruna forum that called Karang Taruna Kelurahan Cibinong. This forum became a place for the youth with various educational background from high school to college to hangout and spend their time. One of the program that karang taruna kelurahan Cibinong have is organizing softskill training. This because there was a large number of karang taruna member have not worked or unemployed. Many unemployed youth is caused by the low skills out competence, competence taking into account the work opportunity, and lack of understanding in test preparation and job selection. Therefore,this activity is aimed to give a skill in entering the work environment by simple career scheme starts from give the knowledge how to looking for a job vacancy until the selection test preparation. This softskill training that provide to the karang taruna kelurahan Cibinong member by simple career scheme is expected to improve their skills and broaden their horizons so they would be more prepared in entering the work environment and to reduce the number of unemployed youth in kelurahan Cibinong.
\end{abstract}

Keywords: Karang Taruna, Kelurahan Cibinong, Simple Career Scheme, Soft skills, Youth.

\section{ABSTRAK}

Organisasi kepemudaan karang taruna merupakan wadah yang dapat membantu pemerintah dalam menyelesaikan permasalahan sosial yang ada di masyarakat. Kabupaten Bogor yang terdiri dari 40 kecamatan merupakan salah satu contoh wilayah yang menjadikan karang taruna sebagai wadah untuk memajukan daerahnya. Salah satunya adalah Kelurahan Cibinong yang berada dibawah Kecamatan Cibinong Kabupaten Bogor memiliki karang taruna yang bernama Karang Taruna Kelurahan Cibinong. Karang taruna kelurahan Cibinong saat ini menjadi wadah tempat berkumpulnya para pemuda dengan berbagai latar pendidikan mulai dari sekolah menengah sampai perguruan tinggi. Salah satu program kerja yang dimiliki oleh karang taruna Kelurahan Cibinong adalah pemberian pelatihan softskill. Hal ini dilatar belakangi oleh banyaknya pemuda dan pemudi yang belum bekerja atau menganggur. Banyaknya pemuda yang mengganggur disebabkan karena rendahnya keterampilan diluar kompetensi, ketidaksesuaian bidang kerja dengan peluang kerja yang ada, dan pemahaman yang minim dalam persiapan test dan seleksi kerja. Oleh karena itu kegiatan pengabdian masyarakat ini ditujukan untuk membekali para pemuda karang taruna Kelurahan Cibinong softskill dalam memasuki dunia kerja melalui pola rumah karir sederhana mulai dari mencari lowongan pekerjaan hingga persiapan test untuk seleksi kerja. Pemberian pembekalan kepada para angkatan muda siap kerja karang taruna kelurahan cibinong melalui pola rumah karir sederhana ini diharapkan dapat meningkatkan keterampilan dan membuka wawasan mereka 
sehingga lebih siap dalam memasuki dunia kerja dan dapat mengurangi jumlah pemuda yang menganggur di Kelurahan Cibinong.

Keywords : Karang Taruna, Kelurahan Cibinong, Pemuda, Rumah Karir Sederhana, Softskill.

Salmah, A., Rahmi, F. Andria., \& Herdiyana. (2020). Pembekalan Angkatan Muda Siap Kerja Karang Taruna Kelurahan Cibinong Melalui Pola Rumah Karir Sederhana. Jurnal Qardhul Hasan : Media Pengabdian kepada Masyarakat, 6(2), 154-162.

\section{PENDAHULUAN}

Karang taruna adalah salah satu bentuk organisasi kepemudaan di Indonesia. Karang taruna merupakan wadah pengembangan generasi muda non-partisan, yang tumbuh atas dasar kesadaran dan rasa tanggung jawab sosial untuk masyarakat khususnya generasi muda di wilayah desa/kelurahan atau komunitas sosial sederajat, yang bergerak dibidang kesejahteraan sosial. Karang taruna memiliki peran strategis dalam pembangunan kesejahteraan sosial karena keberadaan karang taruna yang berada hampir diseluruh desa atau kelurahan bersentuhan langsung dengan penyandang masalah kesejahteraan sosial maupun potensi dan sumber kesejahteraan sosial lainnya. Pemerintah menyadari bahwa tanpa peran serta masyarakat mustahil permasalahan sosial dapat ditangani, untuk itu diharapkan peran serta seluruh potensi dan sumber kesejahteraan sosial termasuk diantaranya karang taruna (Widodo, 2017). Karang taruna dapat diartikan sebagai salah satu organisasi yang keberadaannya telah diakui dan diterima oleh masyarakat. Hal ini dikarenakan karang taruna dianggap sebagai wadah pembinaan dan pengembangan serta pemberdayaan generasi muda yang berkedudukan di desa dan kelurahan yang memiliki struktur keorganisasian yang jelas (Tri Cahyati, 2018). Karang taruna didirikan dengan tujuan memberikan pembinaan kepada para remaja, terutama yang putus sekolah dan menganggur. Jika tidak diberi tambahan pendidikan yang berupa berbagai keterampilan, mereka dapat menimbulkan banyak masalah (Arif dan Agus, 2014).

Kecamatan Cibinong merupakan salah satu kecamatan di Kabupaten Bogor yang terdiri dari 13 kelurahan merupakan salah satu contoh wilayah yang menjadikan karang taruna sebagai wadah untuk memajukan daerahnya. Salah satunya adalah karang taruna Kelurahan Cibinong, yang saat ini menjadi wadah bagi tempat berkumpulnya para pemuda mulai dari lulusan sekolah menengah sampai pada perguruan tinggi. Permasalahan yang ada di Kelurahan Cibinong ini adalah banyaknya para pemuda/di yang belum bekerja dengan latar belakang pendidikan lulusan sekolah menengah, dimana saat ini kelurahan Cibinong yang dihuni oleh 24.426 jiwa penduduk, sebanyak 5.512 orang belum memiliki pekerjaan dengan latar pendidikan didominasi oleh tamatan SMA sebanyak 7.581 orang. Setelah melakukan diskusi dengan Ketua Karang Taruna Kelurahan Cibinong yaitu sdr. Muhammad Afifudin dapat ditarik sebuah kesimpulan bahwa banyaknya pemuda yang belum bekerja mengindikasikan minimnya keterampilan dalam kecakapan hidup (life skill).

Pendidikan kecakapan hidup (life skill), sebagaimana dijabarkan oleh tim Broad Based Education (BBE) Depdiknas ada lima bidang, yaitu self awareness (kecakapan mengenal diri), thinking skills (kecakapan berpikir), social skills (kecapakan sosial), academic skills (kecakapan akademik), dan vocational skills (kecakapan vokasional). Kelima bidang ini sangat penting peranannya guna keberhasilan pendidikan yang memiliki relevansi positif dengan dunia nyata. Sayangnya, tolok ukur kecakapan dalam kurikulum kita lebih 
memprioritaskan pada kecakapan akademik, sementara kecakapan lainnya sangat kurang. Padahal, untuk membekali generasi muda mempunyai wawasan yang luas tentang dunia kerja maupun dunia kemasyarakatan (mengurangi pengangguran) semua kecakapan skill tersebut harus dimiliki oleh generasi muda, utamanya vocational skill (Ashary, 2016).

Permasalahan yang dihadapi oleh karang taruna kelurahan Cibinong nantinya dapat diatasi bersama dengan tim pengabdian dari Fakultas Ekonomi Universitas Pakuan melalui pemberian pelatihan pengembangan diri serta persiapan untuk memasuki dunia kerja. Oleh karena itu, Program Kemitraan Masyarakat ini ditujukan untuk memberikan softskill kepada para pemuda Karang Taruna Kelurahan Cibinong melalui pihak yang kompeten dalam bidangnya dengan maksud untuk meningkatkan kualitas keilmuan dan keterampilan para pemuda serta membuka wawasan para pemuda melalui sharing knowledge. Upaya ini juga bertujuan untuk mengurangi jumlah pemuda yang menganggur di Kelurahan Cibinong khususnya. Pelatihan yang diberikan dimulai dari pelatihan persiapan kerja yaitu penampilan untuk memasuki dunia kerja, pembuatan CV dan teknik wawancara, pelatihan psikotes, dan pelatihan pemanfaatan sosial media untuk memperoleh informasi lowongan pekerjaan.

\section{MATERI DAN METODE}

Karang taruna Kelurahan Cibinong merupakan mitra dari kegiatan pengabdian masyarakat ini. Karang taruna Kelurahan Cibinong memiliki anggota dengan latarbelakang pendidikan yang sangat beragam. Pendidikan terendah para pemuda karang taruna kelurahan Cibinong saat ini adalah Sekolah Menengah Umum (SMU) dan Sekolah Menengah Kejuruan (SMK). Hanya sebagian dari pemuda karang taruna kelurahan Cibinong yang dapat melanjutkan ke jenjang perguruan tinggi. Para lulusan SMU/SMK ini merupakan para pemuda yang memang sedang mencari pekerjaan karena mereka tidak dapat melanjutkan pendidikan ke perguruan tinggi dikarenakan masalah ekonomi. Ketua Karang Taruna Kelurahan Cibinong berharap dengan memberikan keahlian softskill dalam mempersiapkan diri untuk melamar pekerjaan kepada para anggota dapat membantu dan mempercepat para anggota untuk mendapatkan pekerjaan. Kegiatan pengabdian ini juga mendapat dukungan penuh dari Lurah Cibinong dengan menyediakan sarana dan prasarana untuk pelaksanaan kegiatan pengabdian ini.

\section{Pembekalan Grooming, Teknik Wawancara, Pembuatan CV dan Pre- Psikotes}

Kegiatan pembekalan dilakukan di kantor Kelurahan Cibinong. Proses pemberian materi dilakukan selama 1 hari. Kegiatan dimulai dengan pembukaan acara yang dihadiri oleh Lurah Cibinong. Selanjutnya Pemberian materi dibagi menjadi 3 sesi yaitu sesi 1 penyampaian materi mengenai Grooming. Pemberian pelatihan dilakukan melalui kegiatan tutorial. Materi awal adalah menjelaskan bagaimana berpenampilan yang baik, yaitu tips berbusana dalam melamar pekerjaan bagi wanita dan pria, tips kondisi tubuh yang harus dirawat dan diperhatikan, tips memilih warna dan asesoris yang cocok digunakan dalam dunia kerja, tips posisi tubuh ketika berdiri dan duduk yang benar bagi wanita dan pria, serta tips ekspresi wajah dan tingkah laku ketika dalam wawancara kerja.

Sesi 2 pembekalan diisi dengan pemberian pelatihan mengenai teknik wawancara dan pembuatan CV. Pada tahapan ini para pemuda akan diberikan teknik bagaimana membuat curriculum vitae (CV) dengan struktur atau format penulisan yang benar, apa saja informasi yang harus disampaikan didalamnya, serta memberikan contoh $\mathrm{CV}$ yang baik dan benar. Pada sesi ini juga disampaikan materi mengenai teknik dalam wawancara kerja yaitu dokumen apa saja yang harus disiapkan dan dibawa ketika 
akan diwawancara oleh pihak perusahaan dan tips beberapa pertanyaan yang akan ditanyakan.

Sesi 3 digunakan untuk melakukan prepsikotes untuk mengetahui kemampuan peserta dalam psikotes sebelum diberikan kunci-kunci bagaimana menghadapi psikotes pada pertemuan selanjutnya. Pada sesi ini tim PkM didampingi oleh 2 mahasiswa yang membantu untuk teknis pelaksanaan tes. Metode pelatihan yang digunakan pada pelatihan ini dilaksanakan melalui pengajaran tatap muka dua arah antara tutor dan peserta, dengan menggunakan alat bantu berupa infokus, laptop, materi PPT, dan berbagai instrumen yang digunakan seperti kertas tes KreaplinPauli, dan lain-lain.

\section{Pembekalan Tes Umum Psikologi}

Kegiatan pembekalan tes umum psikologi dilakukan di kantor Lurah Cibinong. Proses pemberian materi dilakukan selama 1 hari. Metode pelatihan dilaksanakan melalui pengajaran tatap muka dua arah antara tutor dan peserta, dengan menggunakan alat bantu berupa infokus, laptop, materi PPT, dan berbagai instrumen berupa alat peraga, print out soal-soal test, dan lain-lain. Sesi pembekalan ini diberikan kepada para peserta untuk mengenal dan mampu memahami berbagai tes umum psikologi yang sering digunakan perusahaan dalam melakukan seleksi kerja. Seperti yang dijelaskan oleh (Satryawati dan Wa Ode, 2012) bahwa penempatan pegawai yang tepat tidak terlepas dari pelaksanaan rekruitmen dan proses seleksi yang dilakukan terhadap calon pegawai. Salah satu cara yang dapat dilakukan adalah dengan melakukan tes kemampuan melalui tes psikologi. Tes psikologi merupakan salah satu alat bantu dalam pemeriksaan psikologis yang banyak digunakan oleh seorang psikolog, dikarenakan dengan menggunakan tes psikologi seorang dapat diperoleh gambaran secara cepat, tepat dan obyektif mengenai seseorang, baik gambaran mengenai inteligensinya maupun kepribadiannya (Daulay, 2014). Bentuk alat tes psikologi yang diberikan kepada para peserta adalah test intelegence quotiens (IQ), tes kepribadian, tes gambar, tes kreaplin/pauli, dan tes warteggius.

\section{Pembekalan Penggunaan Sosial Media Untuk Memasuki Dunia Kerja}

Kegiatan pembekalan ini dilakukan di kantor Kelurahan Cibinong. Proses pemberian materi dilaksanakan selama 1 hari. Metode pelatihan dilaksanakan melalui pengajaran tatap muka dua arah antara tutor dan peserta, dengan menggunakan alat bantu berupa infokus, laptop, materi PPT, dan handphone masing-masing peserta. Pada Tahap ini pembekalan yang diberikan berupa Pelatihan dan pendampingan pemanfaatan sosial media yaitu pembuatan akun LinkedIn dan penggunaan aplikasi Robs Jobs melalui handphone. Pada tahapan ini penerapan ipteks dilakukan melalui kombinasi tutorial dan praktik langsung. Pada tahapan ini para peserta diminta untuk mengunduh aplikasi Robs Jobs melalui playstore di handphone masing-masing, dan dipandu bagaimana langkah-langkah penggunaan aplikasi tersebut. Manfaat bagi para pencari kerja menggunakan teknologi seluler yaitu dapat mengetahui lowongan baru secara cepat, kemampuan untuk membuat koneksi dan target yang tepat secara cepat, dan secara strategi dapat mengatur peluang karir dari lokasi manapun. Selain itu para pencari kerja juga dapat mengoptimalkan waktu mereka secara efektif dan mencari pekerjaan secara efisien (Pankratz, 2016). Peserta juga diajarkan bagaimana membuat akun LinkedIn dan bagaimana memperbaharui data profil dalam akun LinkedIn. LinkedIn adalah sebuah alat untuk membangun jaringan profesional yang kuat. LinkedIn dirancang untuk menyatukan orang, memperluas lingkaran jaringan, dan memberdayakan pengguna untuk bertukar informasi (Schneiderman, 2016). Pada praktiknya tim PkM dibantu oleh 2 orang mahasiswa untuk melakukan pengarahan kepada peserta yang mengalami kesulitan 
dalam mengoperasikan aplikasi Robs Jobs dan LinkedIn.

\section{HASIL DAN PEMBAHASAN}

Program kerja yang menjadi fokus dari karang taruna kelurahan Cibinong memberikan pelatihan softskill untuk meningkatkan keterampilan para anggota karang taruna yang merupakan pemuda dan pemudi di Kelurahan Cibinong. Pemberian pelatihan ini dimaksudkan agar para pemuda dapat lebih produktif, mengingat kebanyakan anggota karang taruna ini adalah lulusan sekolah menengah yang belum bekerja dan tidak dapat melanjutkan pendidikan ke jenjang perguruan tinggi karena masalah ekonomi. Pelatihan yang diberikan saat ini kepada para anggota karang taruna hanya dilakukan oleh ketua karang taruna saja sehingga ilmu yang diajarkan masih sangat terbatas.

Berdasarkan kondisi ini akhirnya dosen Fakultas Ekonomi Unpak yang merupakan tim PkM dalam kegiatan pengabdian ini memutuskan untuk melakukan kunjungan ke Kelurahan Cibinong sebagai survey awal untuk menggali lebih dalam kebutuhan dari para pemuda yang tergabung dalam karang taruna Kelurahan Cibinong. Kunjungan ini dihadiri oleh 4 orang dosen Fakultas Ekonomi Universitas Pakuan, Lurah Cibinong dan Staf, serta Ketua Karang Taruna yang juga merupakan mahasiswa dari FE Unpak. Dari hasil kunjungan ini diperoleh beberapa hal yang penting diantaranya :

Pemuda karang taruna Kelurahan Cibinong belum memiliki keterampilan (soft skill) untuk memasuki dunia kerja berupa cara berpenampilan untuk bekerja, membuat CV yang baik dan benar, bagaimana menjawab pertanyaan pada saat wawancara kerja, dan bagaimana menyiasati tes psikologi yang sering dijadikan syarat bagi penerimaan karyawan diberbagai perusahaan. Menurut (Sinambela dan Daniel, 2011) untuk menghasilkan tenaga kerja yang dapat diandalkan umumnya harus melalui suatu proses yang dimulai dari bagaimana calon tenaga kerja itu memasukkan lamaran sampai proses akhir yaitu penilaian apakah calon tenaga kerja tersebut sesuai dengan pendidikan dan keahliannya yang dibutuhkan oleh perusahaan. Untuk itu tim PkM memutuskan untuk memberikan pelatihan mengenai grooming, teknik wawancara dan pembuatan $\mathrm{CV}$, serta pelatihan psikotes.

Para pemuda karang taruna belum memanfaatkan kecanggihan teknologi sosial media untuk membuka peluang dalam memasuki dunia kerja. Padahal di era digital seperti saat ini, teknologi memberikan kemudahan kepada para pencari kerja dalam mendapatkan informasi mengenai peluang kerja yang ada di seluruh Indonesia. Dengan adanya sosial media saat ini mencari pekerjaan dan proses melamar kerja jauh lebih mudah dan murah dibandingkan sebelumnya. Era digital telah membawa para pencari kerja ke tingkat yang baru dengan munculnya sosial media. Melalui sosial media para pencari kerja dapat mengakses pekerjaan yang mereka inginkan dan butuhkan sesuai posisi dan minat mereka langsung ke perusahaan. Para pencari kerja dapat terhubung langsung dengan para CEO perusahaan, manajer perekrutan dan staf perekrut melalui LinkedIn dan mengakses peluang melalui facebook (Weiner, 2016). Untuk memperluas kesempatan para pemuda mendapatkan pekerjaan, tim PkM memberikan pelatihan mengenai penggunaan aplikasi Robs Jobs yang dapat diunduh melalui smartphone yang telah bekerjasama dengan Depnaker. Selain itu tim PkM juga memperkenalkan akun LinkedIn. 
Gambar 1. Kordinasi dengan pak lurah dan ketua karang taruna kelurahan Cibinong.
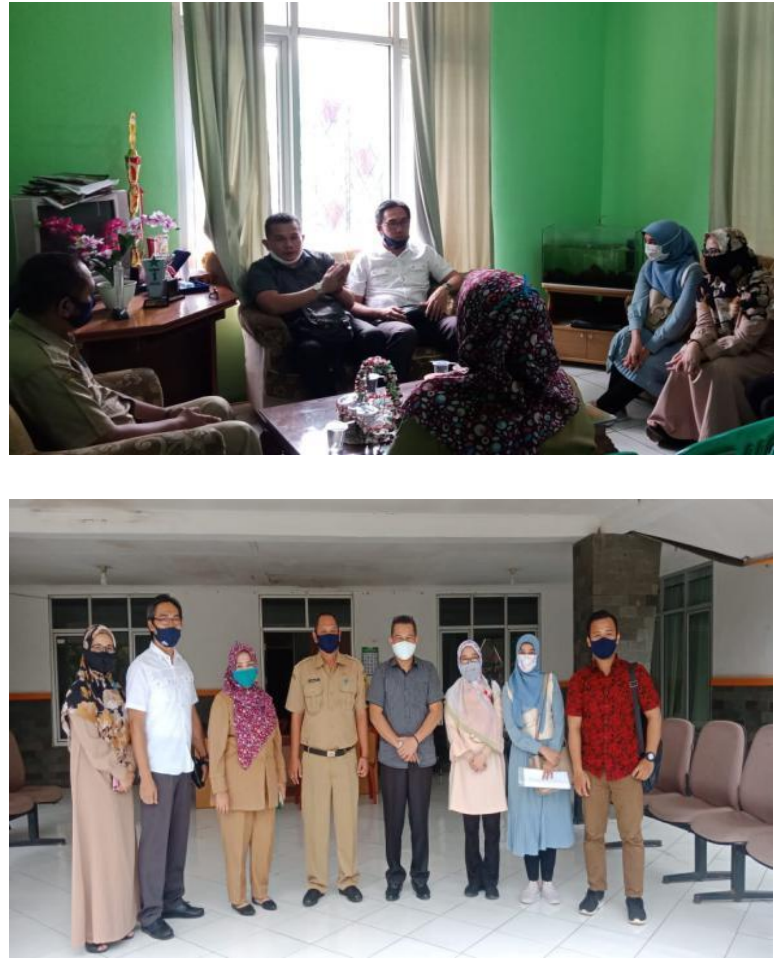

Kegiatan pengabdian ini dimulai dengan memberikan pelatihan mengenai grooming, pemberian keterampilan berupa teknik yang harus dikuasai ketika wawancara kerja dan teknik membuat CV yang menarik bagi perusahaan. Dilanjutkan dengan pemberian pelatihan psikotes untuk membekali para pemuda karang taruna agar dapat lulus dalam tes seleksi kerja yang menggunakan psikotes serta memberikan pelatihan untuk mencari dan melamar pekerjaan dengan memanfaatkan sosial media dan perangkat smartphone yang mereka miliki.

\section{Pelatihan Grooming, Teknik Wawancara, Pembuatan CV dan Pre-Test Psikotes}

Pelatihan ini dilaksanakan pada Kamis, 9 Juli 2020, bertempat di Aula Kantor Kelurahan Cibinong Kabupaten Bogor. Pelatihan ini dihadiri oleh 28 peserta yang terdiri dari anggota karang taruna kelurahan Cibinong, mahasiswa FE Unpak, ketua karang taruna kelurahan Cibinong, lurah cibinong dan staf, dan tim PkM. Setelah mengikuti pelatihan ini para pemuda karang taruna diharapkan dapat berpenampilan sesuai dengan yang disyaratkan dalam dunia kerja, dapat membuat CV yang baik dan benar sesuai dengan format dan dapat menjawab beberapa pertanyaan umum yang sering ditanyakan ketika wawancara kerja dengan jawaban yang tepat. Pelaksanaan dari pelatihan ini ditunjukkan dalam Gambar 2 berikut :

Gambar 2. Pelatihan Grooming, Teknik wawancara, pembuatan cv.
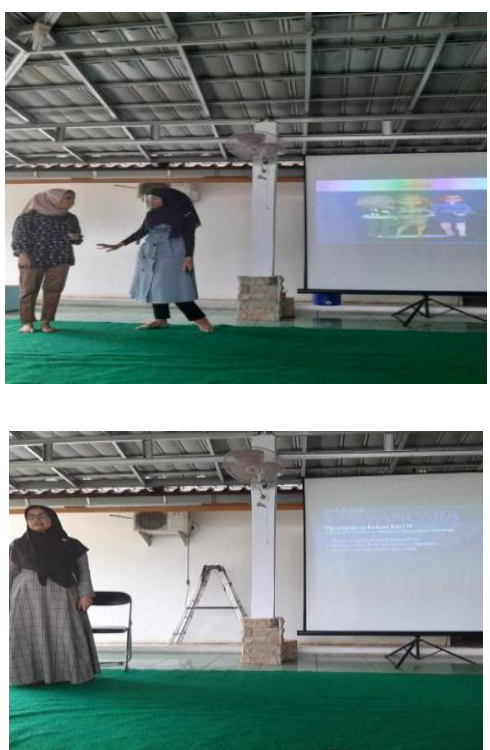

\section{Pelatihan Psikotes.}

Pelatihan ini dilaksanakan pada Kamis, 16 Juli 2020, bertempat di Aula Kantor Kelurahan Cibinong Kabupaten Bogor. Pelatihan ini dihadiri oleh 20 peserta yang terdiri dari anggota karang taruna kelurahan Cibinong, mahasiswa FE Unpak, ketua karang taruna kelurahan Cibinong, dan tim PkM. Pelatihan ini diberikan untuk meningkatkan pengetahuan, kemampuan dan keterampilan para pemuda karang taruna dalam mengerjakan berbagai tes psikotes. Adapun materi tes psikotes yang diberikan dalam pelatihan ini adalah tes kreaplin-pauli, tes intelligence quetient dan warteggius test yang saat ini sering digunakan oleh perusahaan ketika melakukan proses seleksi para calon karyawan. Pelaksanaan pelatihan psikotes ditunjukkan pada Gambar 3 di bawah ini. 
Gambar 3. Pelatihan Psikotes.
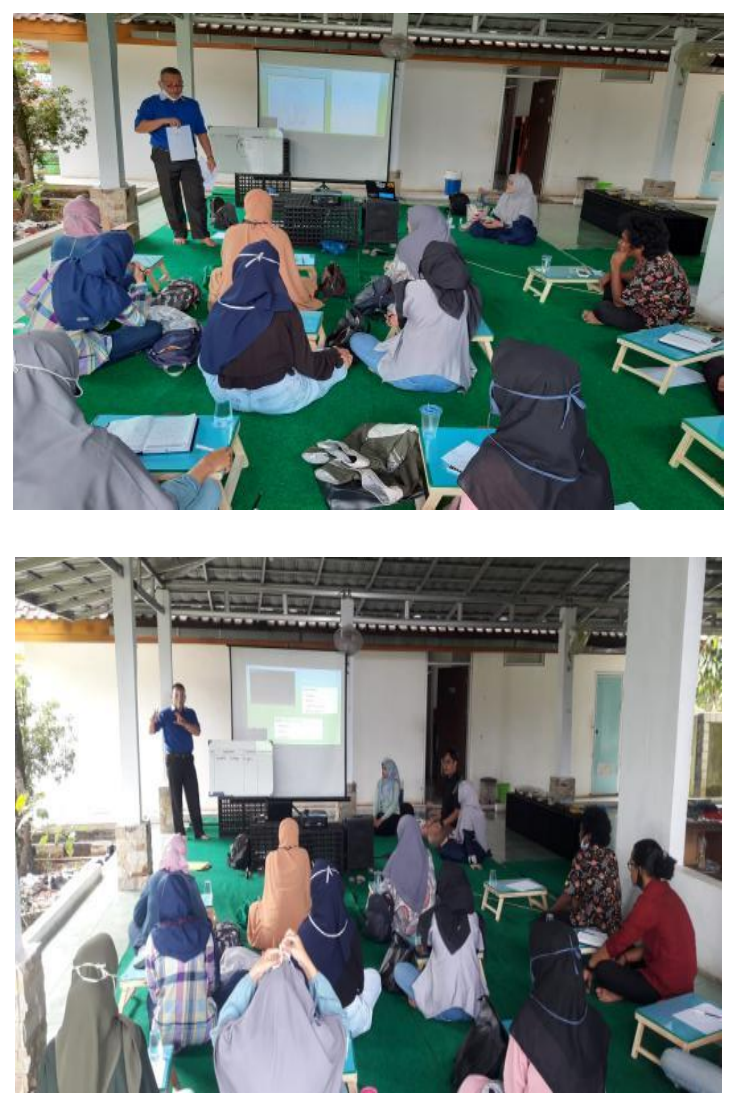

\section{Pelatihan Penggunaan Sosial Media Untuk Memasuki Dunia Kerja.}

Pelatihan ini dilaksanakan pada Senin, 27 Juli 2020, bertempat di Aula Kantor Kelurahan Cibinong Kabupaten Bogor. Pelatihan ini dihadiri oleh 18 peserta yang terdiri dari anggota karang taruna kelurahan Cibinong, mahasiswa FE Unpak, ketua karang taruna kelurahan Cibinong, dan tim PkM. Melalui pelatihan ini para peserta yang merupakan anggota karang taruna Kelurahan Cibinong dapat menggunakan aplikasi Robs Jobs untuk mencari dan melamar pekerjaan melalui smartphone masing-masing sehingga biaya untuk mencetak CV dan mengirim $\mathrm{CV}$ dapat dihemat, dan para pemuda karang taruna juga dapat membangun networking secara profesional dengan menggunakan akun LinkedIn sehingga potensi yang dimilikinya dapat dilihat oleh instansi atau perusahaan yang membutuhkan. Pelaksanaan kegiatan pelatihan ini dapat dilihat pada gambar di bawah ini.
Gambar 4. Pelatihan Penggunaan Sosial Media untuk memasuki Dunia Kerja.
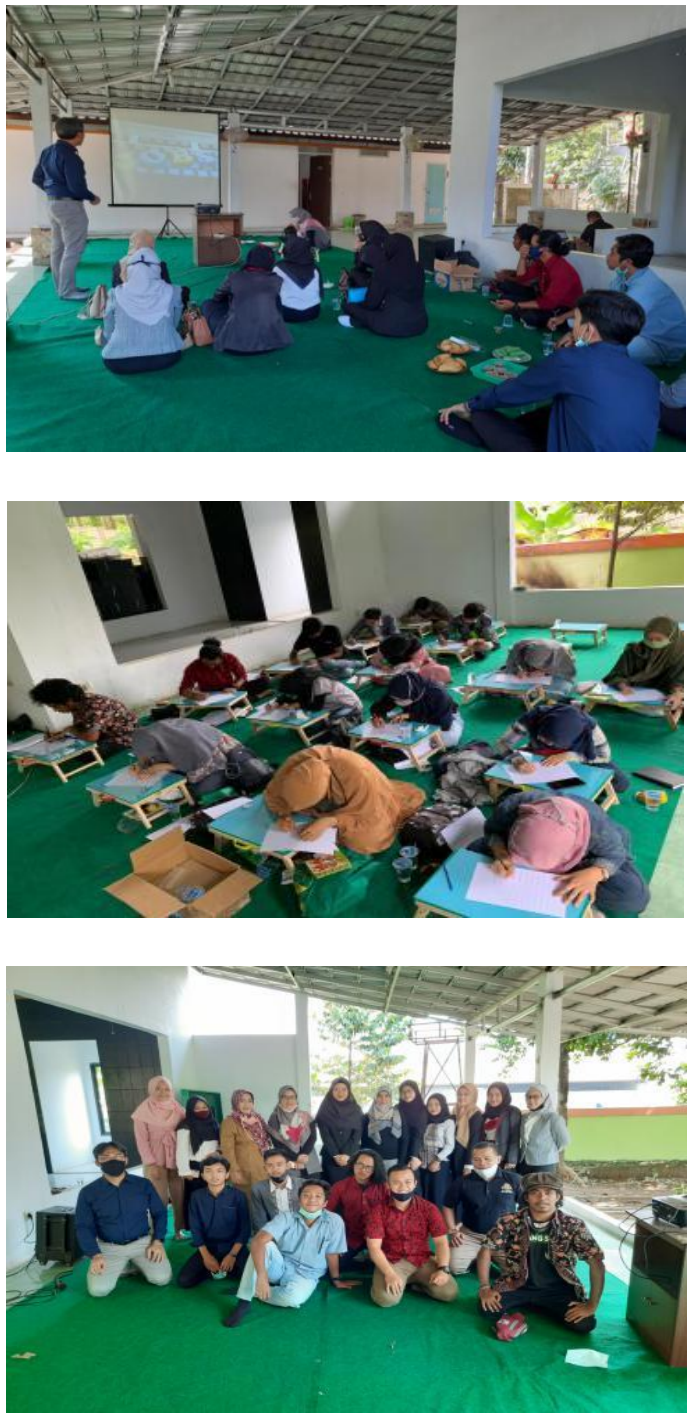

\section{KESIMPULAN}

Kegiatan pengabdian kepada masyarakat mengenai pembekalan angkatan muda siap kerja Karang Taruna Kelurahan Cibinong melalui pola rumah karir sederhana ditujukan untuk meningkatkan keterampilan para pemuda karang taruna Kelurahan Cibinong untuk memasuki dunia kerja. Kegiatan ini juga diharapkan dapat memberikan nilai tambah kepada para pemuda karang taruna Kelurahan Cibinong sehingga lebih percaya diri ketika memasuki dunia kerja dan bisa mendapatkan pekerjaan yang layak.

Para pemuda karang taruna Kelurahan Cibinong sangat antusias dengan pelatihan- 
pelatihan yang diberikan untuk memasuki dunia kerja ini, terutama pelatihan mengenai psikotes karena banyak yang belum tahu dan belum pernah mengerjakan soal-soal psikotes tersebut. Kegiatan pengabdian ini sangat bermanfaat untuk para pemuda karena menambah wawasan dan pemahaman mereka tentang bagaimana menyiapkan diri sebaik mungkin ketika akan melamar pekerjaan dan pada saat proses seleksi kerja oleh perusahaan.Selanjutnya untuk penyelesaian kegiatan ini akan dilakukan monitoring dan evaluasi melalui pembuatan kuesioner melalui media google form yang akan diberikan kepada para peserta pelatihan yaitu pemuda karang taruna, ketua karang taruna, dan lurah Cibinong. Melalui monitoring dan evaluasi ini diharapkan dapat diketahui sejauh apa manfaat yang dirasakan setelah terselenggarnya pelatihan ini.

\section{Implikasi}

Pelatihan soft skill dalam rangka memasuki dunia kerja seperti ini sangat penting untuk diberikan kepada para pemuda, baik untuk lulusan sekolah menengah maupun perguruan tinggi. Hal ini dikarenakan dalam dunia kerja saat ini tidak hanya dibutuhkan keterampilan dari sisi akademik saja namun juga harus diikuti dengan kecakapan hidup (life skill). Minimnya keterampilan di luar bidang akademik seperti keterampilan dalam mempersiapkan diri memasuki dunia kerja mengakibatkan para pencari kerja kehilangan kesempatan yang ada. Pembekalan yang diberikan kepada para pemuda diharapkan dapat meningkatkan pengetahuan, pemahaman dan kemampuan para pemuda dalam mempersiapkan diri untuk memasuki dunia kerja. Selain itu juga diharapkan mampu membantu mengatasi masalah pengangguran di Kelurahan Cibinong dengan mempersiapkan dan membekali pengetahuan kepada angkatan muda siap kerja di wilayah ini mulai dari tahap mencari lowongan kerja sampai pada tahap seleksi kerja. Melihat antusias dan manfaat yang diperoleh oleh para pemuda dari kegiatan ini, diharapkan kegiatan seperti ini dapat menjadi agenda rutin yang dimasukkan dalam program kerja Kecamatan Cibinong sehingga karang taruna yang ada di bawah kecamatan Cibinong juga dapat memperoleh manfaat dari pelatihan ini.

\section{UCAPAN TERIMAKASIH}

Kami mengucapkan terima kasih kepada :

LPPM Universitas Pakuan yang telah memberikan dukungan melalui pendanaan kegiatan pengabdian ini dalam skema Hibah Internal Universitas Pakuan Tahun 2020.

Fakultas Ekonomi Universitas Pakuan atas dukungannya dalam kegiatan pengabdian ini.

Kelurahan Cibinong yang telah memfasilitasi jalannya kegiatan ini dengan memberikan dukungan penyediaan sarana dan prasarana sehingga kegiatan dapat berjalan dengan lancar.

Ketua dan para anggota Karang Taruna Kelurahan Cibinong yang selalu antusias hadir dalam setiap kegiatan.

\section{DAFTAR PUSTAKA}

Arif, Mochamad Ridwan dan Agus Satmoko Adi. 2014. Peran Karang Taruna dalam Pembinaan Remaja di Dusun Candi Desa Candinegoro Kecamatan Wonoayu Kabupaten Sidoarjo. Journal Kajian Moral dan Kewarganegaraan. Nomor 2 Vol. 1 Tahun 2014, hal 190205.

Agustin, Vony. 2012. Kompetensi Lulusan Sarjana Strata 1 (S1) Psikologi dalam Menghadapi Dunia Kerja Pada Mahasiswa Perguruan Tinggi "X". Jurnal Ilmiah Mahasiswa Universitas Surabaya Vol.1 No 1.

Ashary, Luckman. 2016. Optimalisasi Pemberdayaan Karang Taruna dalam Pengembangan Desa Silomukti Kabupaten Situbondo. Prosiding Seminar Nasional. Hal: 725-738. ISBN: 978-602-60569-2-4. 
Daulay, Nurussakinah. 2014. Implementasi Tes Psikologi dalam Bidang Pendidikan. Jurnal Tarbiyah. Vol. 21., No. 2, Juli-Desember 2014: 402-421. ISSN : 0854-2627.

Pankratz, Ruth. 2016. Mobile Technology: Evolutions and Trends For Career Resources, Searches, and Networking. Career Planning and Adult Development Journal. Vol.32 No. 3: 5861. ISSN : 0736-1920.

Satryawati dan Wa Ode Saniah. Peranan Tes Psikologi terhadap Penempatan Pegawai pada Politeknik Negeri Samarinda. Jurnal Eksis Vol. 8 No. 2 Agustus 2012 : 2168 - 2357. ISSN : 0216-6437.

Schneiderman, Kimberly. 2016. Using LinkedIn To Connect. Career Planning and Adult Development Journal. Vol.32 No. 3: 32-37. ISSN : 0736-1920.

Sinambela Sahat dan Daniel Sembiring. 2011. Analisis Perekrutan dan Seleksi
Tenaga Kerja di PT Toray Istem. Jurnal Ilmiah Faktor Exacta, Vol. 4 No. 4 Desember 2011: 317-326.

Tri Cahyati, Fania. 2018. Peranan Karang Taruna dalam Pemberdayaan Pemuda : Studi Kasus terhadap Karang Taruna Eka Kriya di Desa Kalikajar Kecamatan Kaligondang Kabupaten Purbalingga. Jurnal Pendidikan Kewarganegaraan dan Hukum, Vol. 7 No. 6: 636-648.

Weiner, Wendi. 2016. The Influence of Social Media on Job Seekers in the Digital Age. Career Planning and Adult Development Journal. Vol. 32 No. 3: 2631. ISSN : 0736-1920.

Widodo, Ageng. 2017. Kesadaran Karang Taruna dalam Melakukan Intervensi Komunitas : Program Pemberdayaan "Sedekah Pohon Pisang" di Desa Gandri, Lampung Selatan. Jurnal Pemberdayaan Masyarakat. Vol. 1 No. 1 